\title{
MECHANISMS OF PROFESSIONAL COMPETENCE DEVELOPMENT IN FUTURE TEACHERS BASED ON PEDAGOGICAL AND TECHNICAL KNOWLEDGE
}

${ }^{1}$ Dustnazar Omonovich Khimmataliev, ${ }^{2}$ Kakhramon Tanzilovich Olmov, ${ }^{3}$ Ranajon Matyakubovna Abdullaeva, ${ }^{4}$ Bobirjon Bakhodirovich Ergashev, ${ }^{5}$ Khadicha Toshbaevna Chulponova

${ }^{1}$ Doctor of Pedagogical Sciences, Professor, Tashkent Institute of Irrigation and Agricultural Mechanization Engineers, Tashkent, Uzbekistan.

${ }^{2}$ Doctor of Pedagogical Sciences, Professor, Institute of Pedagogical Innovations, Vocational Education Management and Retraining and Advanced Training of Teachers, Tashkent, Uzbekistan.

${ }^{3}$ Candidate of Psychological Sciences, Associative Professor, Tashkent State Economic University, Tashkent, Uzbekistan. ${ }^{4}$ Candidate of Technical Sciences, Associate Professor, Namangan Institute of Engineering and Technology, Namangan,

Uzbekistan.

${ }^{5}$ Senior Lecturer, Tashkent State Transport University, Tashkent, Uzbekistan.

\section{ABSTRACT:}

This article highlights the importance of pedagogical and technical knowledge in the process of preparing future teachers for professional work, the importance of developing their professional competencies, the implementation of a mechanism for improving teachers' professional activity based on an integrative-differential approach, and the formation of specialist in each course of education.

Keywords: competence, competence, integrative-differential approach, integration of pedagogical and technical knowledge, future teacher.

Article Received: 18 October 2020, Revised: 3 November 2020, Accepted: 24 December 2020

\section{Introduction}

The interaction of integration and differentiation in pedagogy has been proven to provide the necessary conditions for the regulation of vocational education and building a hierarchical model.

In modern society, the level of development of a particular country depends not only on its technical condition, but also on the professional competence of specialists in higher education.

Modernization of the education system and changes in the system of vocational training are necessary for the development of professional competence of the staff of the educational institution. Currently, the state educational standards of higher vocational education are introduced and innovations are widely introduced in the content and technology of education aimed at improving the quality of training of future vocational training teachers.

\section{Material and methods}

The English term "competence" literally means "capability". In essence it means "effective use of theoretical knowledge in the activity, demonstration of high professionalism, skills and abilities".

The notion of "competence" came into the field of education as a result of psychological research. Competence is, therefore, "a plan for unconventional situations, how an expert behaves in an unforeseen manner, communicates, takes new steps in interacting with competitors, uses ambiguous tasks, uses conflicting information, and progressively evolves and complex processes".

Professional competence is the acquisition by the specialist of the knowledge, skills and abilities necessary for the implementation of professional activities and their ability to apply it at a high level.

\section{Results and discussion}

Professional competence does not mean the acquisition of individual knowledge and skills 
by a specialist, but rather the integration of integrative knowledge and actions in each independent field. Competence also requires continual enrichment of specialist knowledge, new information, understanding important social requirements, the ability to search for new information, process it and apply it in its activities.

Professional competence is evident in the following cases:

- in complex processes;

- when performing uncertain tasks;

- in the use of conflicting information;

- to have a plan of action in case of unforeseen circumstances

Expert with professional competence:

- consistently enriches his knowledge;

- acquires new information;

- understands the requirements of the time;

- seeks new knowledge;

- They are processed and effectively used in their practical activities.

We will briefly summarize the nature of the qualities reflected in the professional competence. These include: 1) social competence; 2) special competence; 3) personal competence; 4) technological competence; 5) extreme competencies.

1. Social competence - ability to act in social relationships, acquire skills, ability to communicate with subjects in professional activities.

2. Special competence - preparation for the organization of professional and pedagogical activities, rational decision of professional and pedagogical tasks, realistic evaluation of the results of activities, consistent development of knowledge, skills and abilities, based on the competence of psychological, methodical, informative, creative and innovative. competence is apparent. They represent the following content:

1) psychological competence - the ability to create a healthy psychological environment in the pedagogical process, to establish positive relationships with students and other participants of the educational process, to be able to recognize and respond to various negative psychological conflicts in a timely manner;

2) methodological competence methodically rational organization of pedagogical process, proper definition of forms of educational or educational activity, purposeful choice of methods and means, effective use of methods, successful use of means;

3) information competence - search, gathering, sorting, processing, and purposeful, efficient, efficient use of necessary, important, necessary, useful information in the information environment;

4) creative competence - a critical, creative approach to pedagogical activity, the ability to demonstrate their creative skills;

5) innovative competence - promotion of new ideas on the improvement of the pedagogical process, improvement of the quality of education, increasing the effectiveness of the educational process, their effective implementation;

6) communicative competence - the ability to communicate warmly with all participants of the educational process, including students, to be able to listen to them and to have a positive impact on them.

7)personal competence - consistent achievement of professional growth, professional development, demonstration of internal capabilities in professional activity.

8) Technological competence - the ability to use advanced tools, techniques and technologies to master advanced technology to enrich vocational and pedagogical knowledge and skills.

9) Extremely competent - ability to make wise decisions and behave in emergency situations (natural disasters, technological processes) and in case of pedagogical conflicts [1].

According to N.Muslimov and K.Abdullaeva, competence is the degree of independent and creative application of a set of theoretical knowledge, skills and abilities acquired 
in practice, which also shapes the student's practice and post-graduate activities.

The concept of competence is defined as the ability to apply knowledge, skills, personal qualities and practical experience to successful work in a particular area.

The most complete psychological forms of the professional development of the person in the process of professional self-management in modern socio-economic conditions, features of the development of professional competence were studied by E.F. Zeer. Assesses professional competence as one of the main components of the structure of professional activity, as well as the personality, orientation, professional qualities, and psychologically important features of the personality.

T.M. Sorokina's in studies, the professional competence of the teacher is interpreted as a unit of theoretical and practical training for pedagogical activity. His teaching competence is one of the stages of professionalism that is the basis of the teacher's pedagogical activity.

V.N. According to Vvedensky, the concept of "professional competence" is characterized by the breadth of content, integrated features that combine common concepts such as "professionalism", "qualifications" and "professional competence". However, the identification of the concept under consideration with that concept is still often "competent." Competence is an individual and a set of professional or functional characteristics.

\section{M.I. Lukyanova understands the} characteristics of a person with a high level of professional training and effective interaction with students in the learning process, based on the psycho-pedagogical potential of the teacher. As a component of psychological and pedagogical competence, he considers blocks of psychological and pedagogical orientations.

A.V. Khutorsky distinguishes between the concepts of "competence" and "competence" between "synonymically used". Competence is a complex set of interpersonal characteristics (knowledge, skills, methodology of activity) that are defined for specific topics and processes that are necessary for the production of qualitatively.

G.M. Kodjaspirova believes that "a teacher must have certain pedagogical competence in order to become a competent teacher".

"Competence is a shared ability based on knowledge, experience, values, and intentions acquired through education. Does not fall under the competence knowledge or skills; competence does not mean being a scientist or an educated person ". It is important to distinguish between competence and skills. Skill is a characteristic that can be learned from observations of behavior, competence - behavior in a particular situation. Thus, skills are seen as competencies in practice. Competence is a skill, something that enhances mobility. Competence is formed as a result of conscious activity.

Implementation of the mechanism for improving the professional training of teachers of professional education on the basis of an integral and differential approach will be carried out step by step in accordance with the formation of the specialist in each course of education. At the stage of understanding the status of a student, there is a holistic development of the individual, his or her preparation for a new professional activity is related to the development and acquisition of common fundamentals of the profession.

Students often have no differentiation in their roles during the individual's exposure to others. Students are attached to the students' lifestyles, and to the basic forms of community life. At this stage, the student has developed a new attitude towards the new profession, adjusting to the life of the high school.

Integration of pedagogical and psychological theoretical and practical knowledge in preparation for professional activities, interdisciplinary integration, and systematic approach to improving students' professional competence based on integration of pedagogical and technical knowledge in diagnosing 
preparation for professional activities. Therefore, a systematic approach to the integration of pedagogical and technical knowledge in the diagnosis of vocational training. The mechanism of development of such competences as mobility, reflexivity, integrality in theoretical, practical, research and training directions was improved based on the classification of stages of formation of personal and professional qualities of future specialists.

At the stage of professional selfknowledge (II year), the development of the student's personality will continue, their cultural needs and needs will be shaped. They encompass all forms of education and upbringing, trust and independence, but also actively participate in the work of public organizations and movements. In this period, the emphasis is placed on the professional sciences.

At the stage of professional selfdetermination (III year), students' attention to specialization subjects will be enhanced and their motivation to improve their preparation for professional activities will be strengthened. At this stage, specialization begins, increases the interest in research, learns about the specifics of the chosen profession. At the same time, students' social activity will be developed and, as a rule, their self-organization will be increased.

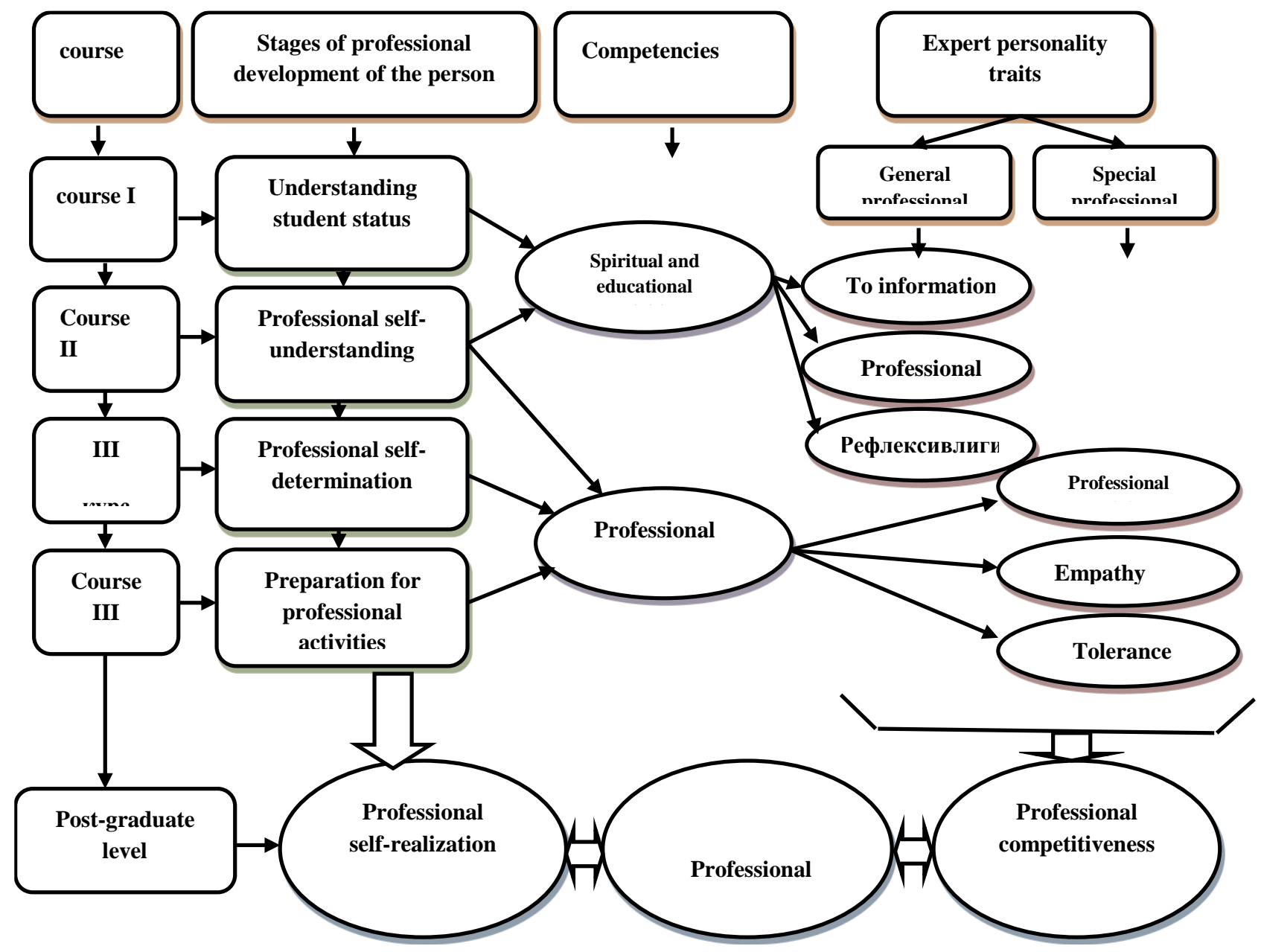

Figure 1. The mechanism of development of professional competence of students on the basis of pedagogical and technical knowledge

Career Development (Vocational Training) Phase IV (Course IV) encourages the acquisition of specialist work methods and technologies related to future career planning. At this stage, the need to choose a place of practice to apply in the practice of professional activities is more conscious. At each stage of improving students' readiness for professional activities, the main 
emphasis is on the peculiarities of the professional

professional activities

[9] (Figure 1). features of improving the readiness of

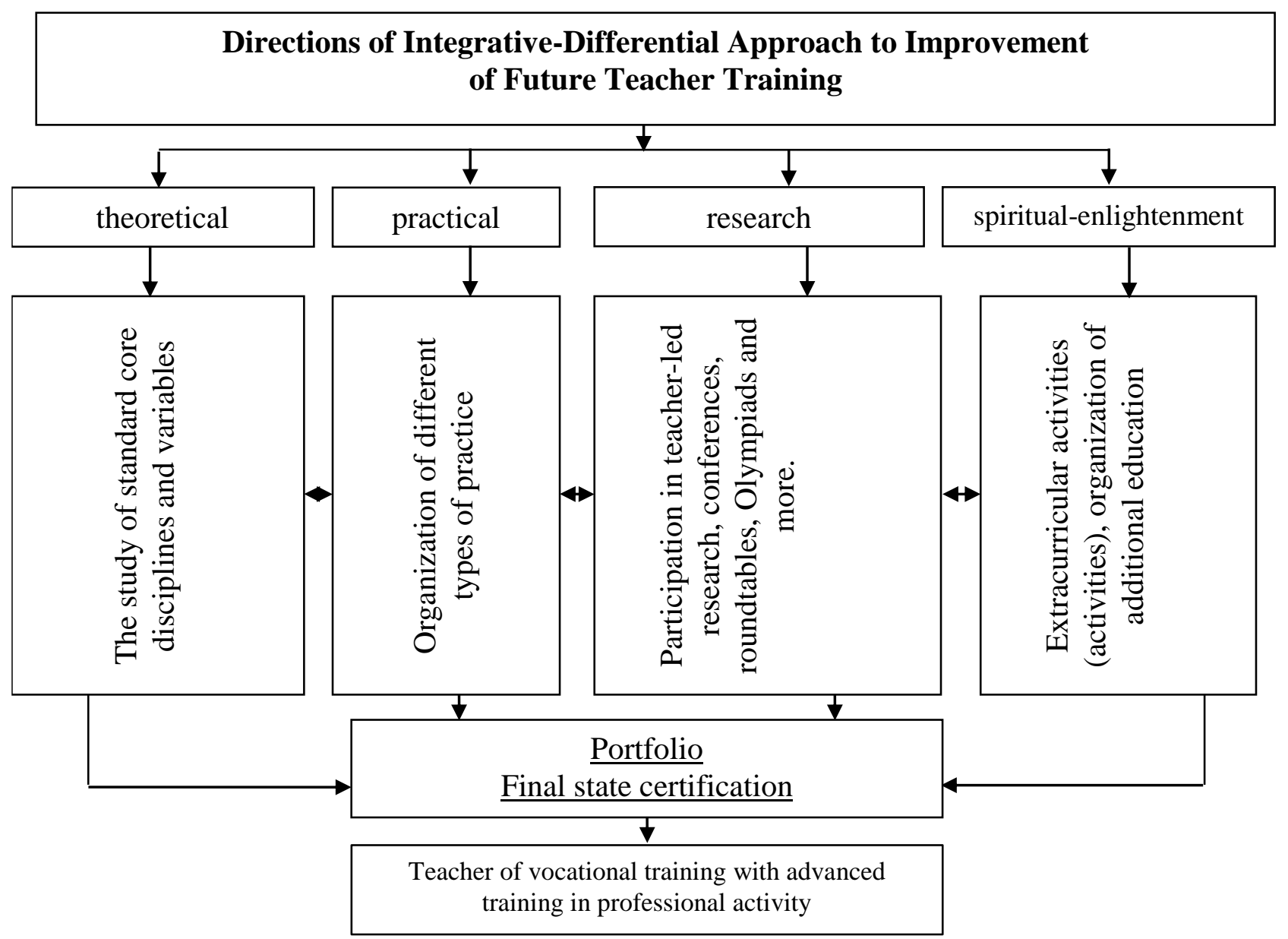

Figure 2. Integrative-differential approach to the development of professional competence of students

\section{Conclusions}

As the theoretical direction of our aforementioned ideas, it implements all blocks and models of the content of preparation for professional activity within the State educational standards; Practical direction - provides various types of practice- training, pedagogical acquaintance, pedagogical, production, pregraduation, etc .; research direction - opens the organizational foundations of vocational training in the system of preparation for professional activity, according to which it can be built in the course of education or in parallel with it; spiritual, educational and ethical direction - provides cultural, recreational, professionally-oriented, civic-legal, informational, spiritual, educational and public events in various activities.
References

[1] Muslimov NA, Usmanbaeva M., Mirsolieva M. Educational-methodical complex on the module "Innovative educational technologies and pedagogical competence" - T: -2016. - $147 \mathrm{p}$.

[2] Professional pedagogy: category, ponyature, definitsii [Text]: sb. nauch. tr Vyp. 4 / Feder. agentstvo po obrazovanyiyu; Ros. gos. Prof. Ped. un-t; Ros. acad. obrazovaniya, Ur. otd-nie, 2006. - $571 \mathrm{p}$.

[3] Muslimov NA, Abdullaeva Q. Some issues of developing the professional competence of future vocational college teachers. / Materials of the Republican scientific-practical conference "Theory 
and practice of professional development of pedagogical and administrative personnel of higher education institutions". - Tashkent: TSPU, 2012. pp. 26-28.

[4] Vvedensky V.N. Modeling Professional Professionals Pedagogy [Text] / V.N. Vvedensky // Pedagogy. - 2003. - No. 10. p. 51-55.

[5] SorokinaT.M. Развитие государственные спецции будущего учителя средствами integratedirovannogo учебного старержания [Text] / T.M. Sorokina// Начальная школа. - 2004. - No. 2. - p. 110-114.

[6] Alimov A. A., Olimov K. T., Gaffarov A. K. Preparing Future Teachers of Vocational Education for Innovative Activity in Uzbekistan //Eastern European Scientific Journal. - 2018. - №. 2.

[7] Ismailova, Z., Choriev, R., Ibragimova, G., Abdurakhmanova, S., \& Abdiev, N. (2020). Competent model of Practiceoriented education of students of the construction profile. Journal of Critical Reviews. Innovare Academics Sciences Pvt. Ltd. https://doi.org/10.31838/jcr.07.04.85

[8] Karabaevna, I. Z., Omonovich, K. D., Abduqunduzovna, B. G., Farmonovna, B. Z., \& Raxmatullaevna, R. L. (2020). Content of development of students educational activity in the context of mobilization of education. Journal of Critical Reviews. Innovare Academics Sciences Pvt. Ltd. https://doi.org/10.31838/jcr.07.05.77

[9] Karabaevna, I. Z., Omonovich, K. D., Murodillaevich, K. N., Normuminovna, S. U., \& Mahmatqulovich, A. O. (2020). Formation of a system of methods of technical thinking future engineers. Journal of Critical Reviews. Innovare Academics Sciences Pvt. Ltd. https://doi.org/10.31838/jcr.07.05.161
[10] Ismailova, Z. K., Khimmataliev, D. O., Khashimova, M. K., Baybaeva, M. K., \& Ergashev, B. B. (2020). Integrative approach to designing the content of secondary specialized vocational education. Opcion, 36(91), 25-41.

[11] Ismailova, Z., Choriev, R., Musurmanova, A., \& Aripjanova, M. (2020). Methods of training of teachers of university on advanced training courses. Journal of Critical Reviews. Innovare Academics Sciences Pvt. https://doi.org/10.31838/jcr.07.05.85

[12] Karabaevna, I. Z., Riskulova, K., Ubaydullaevich, A. M., Turaevna, I. Y., \& Ravshanovna, P. N. (2020). The role of electronic pedagogical tools in higher education. Journal of Critical Reviews. Innovare Academics Sciences Pvt. Ltd. https://doi.org/10.31838/jcr.07.05.80

[13] Ismailova, Z., Choriev, R., Salomova, R., \& Jumanazarova, Z. (2020). Use of economic and geographical methods of agricultural development. Journal of Critical Reviews. Innovare Academics Sciences Pvt. https://doi.org/10.31838/jcr.07.05.84

[14] Ismailova, Z., Khimmataliev, D., Khashimova, M., Fayzullaev, R., \& Sadikova, F. (2019). The role of modern women in society and family. Opcion, 35(Special Issue 21), 734751

[15] Olimov K. T. et al. Interdisciplinary integration-the basis for diagnosis of preparation for professional activity //Solid State Technology. - 2020. - P. 246-257.

[16] Olimov K. T. et al. Competent training of future specialists on the basis of acmelogical approach //Journal of Critical Reviews. - 2020. - T. 7. - №. 15. - P. 2476-2483.

[17] Olimov K. T et al..Introduction of dual training in the system of continuous professional education. European Journal 
of Research and Reflection in Educational Sciences// -2020. Volume 7 Number 12, 2019 Part VI. P. 509-512

[18] Olimov K. T. et al. Teaching Special Subjects for Students with Disabilities in Preparation for the Profession by Using Innovative Educational Technologies //International Journal of Innovative Technology and Exploring Engineering (IJITEE). - 2019. - T. 9. - C. 425-429.

[19] Olimov K. T. et al. Integration of Special Subjects, Opportunities and Solutions//Eastenr European Scientific Journal. - 2019. - №. 2. P. 67-70

[20] Olimov K. T. et al. Scientific researches for development// Scientific researches for development future. -2019. Volume1 P. 38-39

[21] Khutorskoye, A.V. Keywords like a component lichnostno-orientirovannoy paradigmy [Text] / A.V. Хуторской // Народное образование. - 2003. - No. 2. S. 58-64.

[22] Khamidov J.A. Technology of creation and application of modern didactic means of teaching in the training of future teachers of vocational education: Abstract of the doctoral dissertation (DSc) on pedagogical sciences. -Tashkent, 2017.

[23] Khimmataliev D., Khakimov J., Daminov O., Rakhmatova F. Criteria and indicators for assessing the level of professional training of future teachers of vocational training at a training module // Journal of critical reviews. ISSN - 2394-5125. Vol 7, Issue 5, $2020 \quad-\quad$ p. 428-431. doi:10.31838/jcr.07.05.89

[24] Khimmataliev D.O. Integration of pedagogical and technical knowledge in the diagnosis of preparation for professional activity. Monograph. Tashkent, Uzbekistan, 2018 - 168 p.
[25] Khimmataliev D.O. Integration of pedagogical and technical knowledge in the diagnosis of professional training: Doctorate in Pedagogical Sciences (DSc) diss. avtoref. - T.$: 2018$. -70 b 120

[26] Khimmataliev D.O., Baybaeva M.X. Use of modular training opportunities. Monograph. - T.: Uzbekistan, 2017. - 132 p.

[27] Khimmataliev D.O. Integration of scientific knowledge in preparation for the professional activities of future teachers of vocational education // School of the future. Moscow, 2016. No. 6. -S. 50-54. 